\title{
Erratum to: Effects of environmental factors on functional properties of Chinese chestnut (Castanea mollissima) protein isolates
}

Jiao Lv $\cdot$ Yuan Zhao $\cdot$ Jianzhong Wang $\cdot$ Jie Ouyang $\cdot$ Fengjun Wang

Published online: 7 May 2015

(C) Springer-Verlag Berlin Heidelberg 2015

Erratum to: Eur Food Res Technol (2015) 240:463-469

DOI 10.1007/s00217-014-2366-x

The original publication has listed two corresponding authors for this paper. The only corresponding author for this paper is Fengjun Wang.

The online version of the original article can be found under doi:10.1007/s00217-014-2366-x.

J. Lv $\cdot$ Y. Zhao $\cdot$ J. Wang $\cdot$ J. Ouyang $\cdot$ F. Wang $(\bowtie)$

Department of Food Science, College of Biological Sciences and Technology, Beijing Forestry University, Beijing 100083, China

e-mail: wangfengjun@bjfu.edu.cn

J. Lv

e-mail: 869913162@qq.com 